FIU Law Review

Fall 2013

\title{
An Evolving Society: The Juvenile's Constitutional Right Against a Mandatory Sentence of Life (and Death) in Prison
}

Robert Visca

Florida International University College of Law

Follow this and additional works at: https://ecollections.law.fiu.edu/lawreview

Part of the Other Law Commons

Online ISSN: 2643-7759

\section{Recommended Citation}

Robert Visca, An Evolving Society: The Juvenile's Constitutional Right Against a Mandatory Sentence of Life (and Death) in Prison, 9 FIU L. Rev. 159 (2013).

DOI: https://dx.doi.org/10.25148/lawrev.9.1.32

This Comment is brought to you for free and open access by eCollections. It has been accepted for inclusion in FIU Law Review by an authorized editor of eCollections. For more information, please contact lisdavis@fiu.edu. 


\title{
An Evolving Society: The Juvenile's Constitutional Right Against a Mandatory Sentence of Life (and Death) in Prison
}

\author{
Robert Visca ${ }^{*}$
}

\section{INTRODUCTION}

On June 25, 2012, the United States Supreme Court (“Court”) decided Miller v. Alabama, ${ }^{1}$ holding that it is unconstitutional to sentence juvenile homicide offenders to mandatory life-without-the-possibility-of-parole. ${ }^{2}$ With a clear holding in place, the only debatable aspect of Miller is the underlying spirit and intent of this decision. The majority's discussion and reasoning appears to support a broad interpretation of the holding. This piece analyzes how courts and state actors are or should be applying Miller under this broad interpretation.

The American juvenile justice system was founded on a principle that should still hold true today: juvenile offenders can be rehabilitated. ${ }^{3}$ This belief is based on society's recognition that juveniles are developmentally unique from adults. ${ }^{4}$ Behavioral and neuroscientific research on adolescent development indicates that juveniles lack crucial reasoning and riskassessment cognitive capabilities. ${ }^{5}$ In making decisions, juveniles "lack the experience, perspective, and judgment to recognize and avoid choices that could be detrimental to them." 6

Furthermore, juveniles do not assess risk in the same way that adults do, because juveniles erroneously focus only on short-term consequences and fail to accurately consider the long-term consequences of their actions. ${ }^{7}$ Other important differences include the fact that "adolescents are more

* Florida International University College of Law, J.D. 2014; University of Florida B.S. 2010. I thank Professor Leonard P. Strickman and Professor Angelique Ortega Fridman for their guidance as I researched and wrote this Comment; and my parents, Silvio and Linda Visca for their support and encouragement.

1132 S. Ct. 2455 (2012).

2 Id. at 2475.

3 Danielle R. Oddo, Removing Confidentiality Protections and the "Get Tough" Rhetoric: What Has Gone Wrong With the Juvenile Justice System?, 18 B.C. THIRD WORLD L.J. 105, 105 (1998).

4 Id. at 106.

5 Emily C. Keller, Constitutional Sentences for Juveniles Convicted of Felony Murder in the Wake of Roper, Graham \& J.D.B., 11 ConN. PuB. INT. L.J. 297, 312-13 (2012).

6 Id. at 312 (citation omitted).

7 Id. at 313. 
[Vol. 9:159

susceptible to peer pressure than are adults, ${ }^{, 8}$ and the personality traits of a juvenile are more likely to change as the juvenile continues to develop and mature. $^{9}$

In the past, these apparent differences made juveniles less accountable in the eyes of the public, and illegitimate behavior at this early age was generally viewed as the result of correctable developmental deficiencies. ${ }^{10}$ Thus, in rehabilitating juveniles, the criminal justice system preferred a clinical, rather than punitive, approach. ${ }^{11}$ The two general rationales for this approach were that "children are amenable and responsive to treatment, and this treatment was necessary to make up for the care which they were denied for most of their young lives."12 Furthermore, allowing for "wide judicial discretion" was key for successful rehabilitation because individualized attention would provide juveniles the best opportunity to receive appropriately tailored treatment. ${ }^{13}$

There may be no better evidence of how society views the mental capabilities of juvenile offenders than by the way various laws typically provide exceptions or different standards and treatment for individuals under the age of eighteen. No individual under this age has full autonomy, as several laws create restrictions on the juvenile's ability to make certain decisions. ${ }^{14}$

Juveniles do not have the "authority to vote, serve on a jury, create a binding legal contract, purchase and possess a firearm, serve in the military, [ ] gamble," or consume alcohol. ${ }^{15}$ Moreover, there are several activities that a juvenile cannot engage in without parental consent in most states, "including getting an abortion, getting married, purchasing pornography, getting a tattoo, or getting a body piercing."16

However, society's confidence that a rehabilitation system would be most effective in handling juveniles began to waver over time. ${ }^{17}$ "[A]s juvenile crime rates [increased], and the stories of juveniles committing serious and violent crimes... received widespread and sensationalized coverage, the public ... increasingly perceived that the nation [was] under

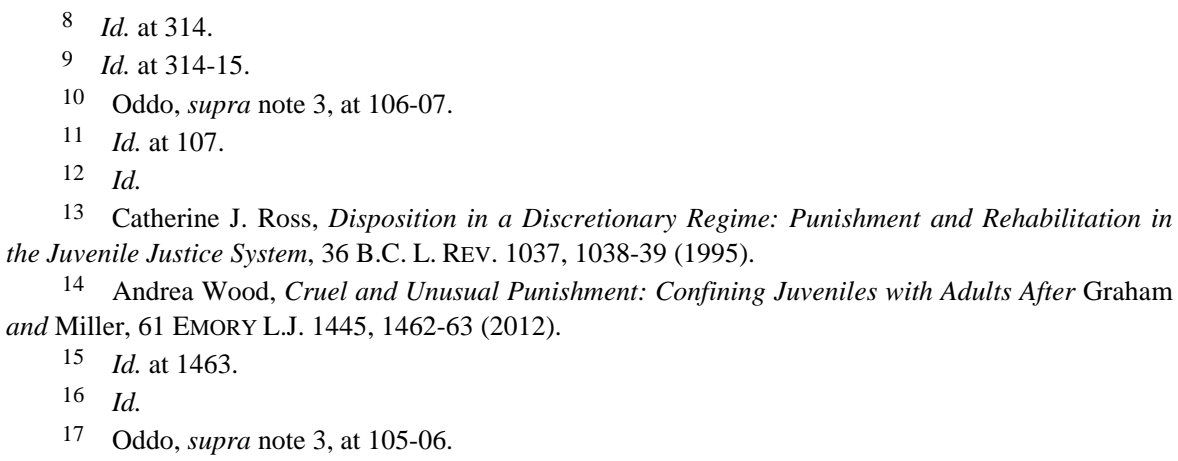


siege."18

In the 1990s, this growing public fear led to state legislatures reworking their transfer procedures to allow for juveniles to be tried as adults for their crimes. ${ }^{19}$ "Between 1990 and 1999, the number of juveniles held in adult jails increased by more than $300 \%$, while the overall adult jail inmate population only increased by $48 \% .{ }^{20}$ Naturally, juveniles would begin receiving longer and harsher sentences, such as life-without-thepossibility-of-parole, which "places emphasis on retribution rather than rehabilitation." 21

By 2012, over 2,500 individuals had been incarcerated to life-withoutthe-possibility-of-parole for crimes they had committed as juveniles. ${ }^{22}$ While this type of harsh sentence may be appropriate for certain crimes committed by both adults and juveniles, the psychological and developmental differences between these groups require that special care be taken before imposing it on juveniles.

The Court has recognized the need to treat juveniles differently and has been curbing the excessive sentencing practices towards juveniles on a case-by-case basis for decades. Miller is the Court's most recent decision attempting to protect juveniles from unconstitutionally disproportionate punishments under the Eighth Amendment ${ }^{23}$ by eliminating mandatory lifewithout-the-possibility-of-parole sentences for juvenile homicide offenders. $^{24}$

However, as affected cases (old and new) reach local dockets, and as states across the country attempt to move forward under Miller, a survey of the revamped juvenile-sentencing landscape reveals a troubling trend: the Court's apparent intent in Miller to guarantee individualized sentencing for juvenile homicide offenders ${ }^{25}$ is being side-stepped.

Part I of this note explores the Court's pre-Miller Eighth Amendment cases that specifically deal with the constitutionality of sentencing practices.

\footnotetext{
18 Id. at 105

19 Wood, supra note 14, at 1458-59.

20 Howard N. Snyder \& Melissa Sickmund, Juvenile Offenders and Victims: 2006 National $\begin{array}{llllll}\text { Report, U.S. } & \text { DEP’T } & \text { OF } & \text { JUSTICE }\end{array}$ http://www.ojjdp.gov/ojstatbb/nr2006/downloads/NR2006.pdf.

21 See Oddo, supra note 3, at 113.

22 Against All Odds: Prison Conditions for Youth Offenders Serving Life without Parole Sentences in the United States, Human Rights WATcH 8 (Jan. 2012), http://www.hrw.org/sites/default/files/reports/us0112ForUpload_1.pdf.

23 The Eighth Amendment to the United States Constitution states: "Excessive bail shall not be required, nor excessive fines imposed, nor cruel and unusual punishments inflicted." U.S. CONST. amend. VIII.

24 Miller v. Alabama, 132 S. Ct. 2455, 2475 (2012).

25 See id.
} 
[Vol. 9:159

Part II examines the Court's decision in Miller, looking at the rationale and argument for and against life-without-the-possibility-of-parole sentences for juveniles. Part III identifies how courts across the nation have properly been interpreting and applying Miller to juvenile cases. Part IV analyzes the ways that state entities and courts can and have side-stepped the spirit of Miller and argues that courts should abide by the intent of Miller by providing every juvenile homicide offender with a meaningful hearing for courts to consider all mitigating factors before imposing a sentence of lifewithout-the-possibility-of-parole.

\section{CASE PRECEDENT PRECEDING MILLER}

Over the past century, the Court has decided several cases that have shaped how courts impose sentences under the Eighth Amendment. The Court has gained momentum in its sentencing jurisprudence over the past few decades, culminating in the Miller decision. While any decision from the Court may be met with criticism or disagreement from one group or another, reviewing case precedent is an important tool when trying to understand how a present-day decision is reached. A review of the cases preceding Miller clearly establishes the reasoning and trends that foreshadowed Miller.

\section{A. Principle of Proportionality}

There are countless cases that address Eighth Amendment issues, but Weems v. U.S. ${ }^{26}$ is arguably the first link in the long chain of cases leading up to Miller. The Court in Weems was faced with the issue of whether a sentence of hard labor for falsifying government documents, which was imposed by a court in the Philippine Islands, constituted cruel and unusual punishment. ${ }^{27}$

In overturning the sentence, the Court discussed the fact that there is no clear definition of cruel and unusual punishment and implied that the punishment should fit the crime. ${ }^{28}$ The Court referenced the view that "it is a precept of justice that punishment for crime should be graduated and proportioned to [the] offense." 29 This principle would form part of the foundation for the Court's current view on determining the constitutionality of sentencing.

\footnotetext{
26217 U.S. 349 (1910)

27 Id. at 357-58.

28 Id. at $368-70$

29 Id. at 367.
} 


\section{B. Evolving Standards of Decency \& Objective Indicia}

In Trop $v$. Dulles,$^{30}$ the controversial punishment was the stripping of a military deserter's citizenship, ${ }^{31}$ and the Court reiterated Weems by pointing out the ambiguity of the Eighth Amendment language. ${ }^{32}$ The Court determined that " $[t]$ he Amendment must draw its meaning from the evolving standards of decency that mark the progress of a maturing society."33 The evolving decency standard would become a central question in future Eighth Amendment cases. ${ }^{34}$

In Gregg v. Georgia, ${ }^{35}$ the Court clarified how the "contemporary values concerning the infliction of a challenged sanction" should be assessed. ${ }^{36}$ The Court must "look to objective indicia that reflect the public attitude toward a given sanction. ${ }^{\text {„3 }}$ The Court further stated that, while important, public perceptions are not necessarily conclusive. ${ }^{38}$

The Court elaborated on this objective indicia analysis in Coker v. Georgia. $^{39}$ In Coker, the Court stated that Eighth Amendment determinations should not be "merely the subjective views of individual Justices; judgment should be informed by objective factors to the maximum possible extent." ${ }^{40}$ This point was later reiterated in Rummel v. Estelle. ${ }^{41}$ An example of an objective indicium utilized by the Court is a state's actual sentencing practices in applying a law. ${ }^{42}$

\section{Mitigating Circumstances \& Youth}

Another important development in this Eighth Amendment jurisprudence is the need for courts to consider all of an offender's mitigating circumstances before imposing the harshest penalties possible. Initially, the Court suggested in Furman v. Georgia ${ }^{43}$ that leaving the

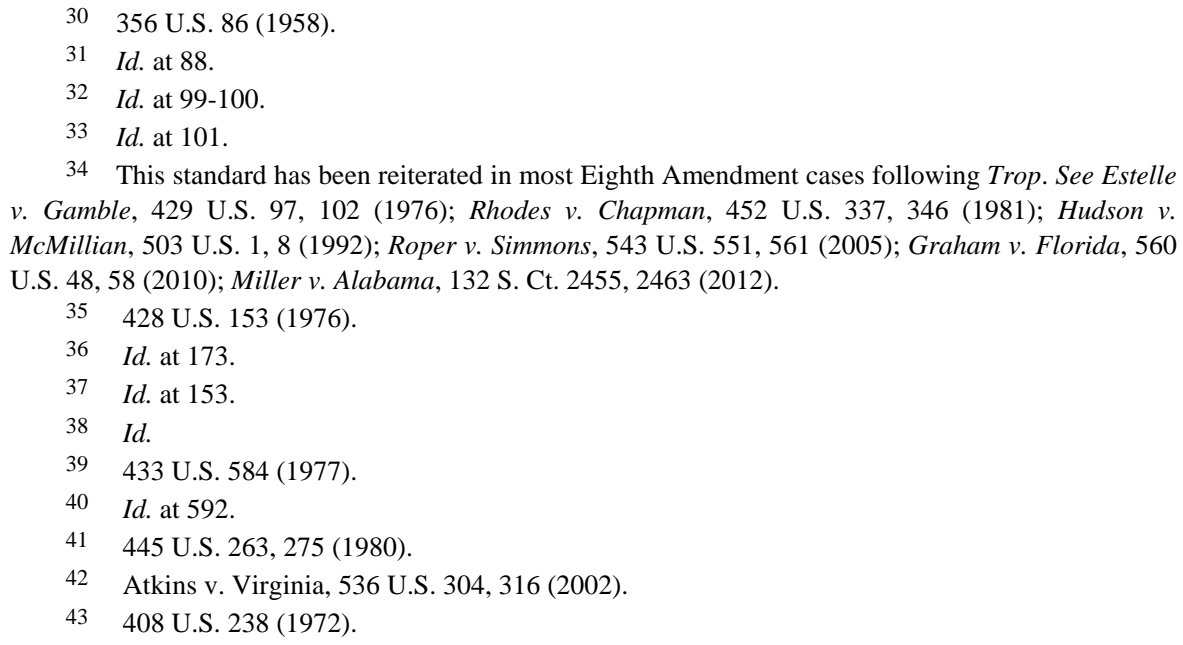

34 This standard has been reiterated in most Eighth Amendment cases following Trop. See Estelle v. Gamble, 429 U.S. 97, 102 (1976); Rhodes v. Chapman, 452 U.S. 337, 346 (1981); Hudson v. McMillian, 503 U.S. 1, 8 (1992); Roper v. Simmons, 543 U.S. 551, 561 (2005); Graham v. Florida, 560 U.S. 48, 58 (2010); Miller v. Alabama, 132 S. Ct. 2455, 2463 (2012).

35428 U.S. 153 (1976).

36 Id. at 173.

37 Id. at 153.

Id.

433 U.S. 584 (1977).

Id. at 592.

445 U.S. 263, 275 (1980).

Atkins v. Virginia, 536 U.S. 304, 316 (2002).

408 U.S. 238 (1972). 
imposition of a death penalty sentence up to the discretion of the judges was dangerous and should be prohibited. ${ }^{44}$ But the Court clarified this decision with its rulings in several similar cases that followed.

In Roberts v. Louisiana, ${ }^{45}$ Woodson v. North Carolina, ${ }^{46}$ and Sumner v. Schuman, ${ }^{47}$ the Court held that it is unconstitutional to impose mandatory death penalties on offenders. ${ }^{48}$ The Court specifically stated in Woodson that it is important to "allow the particularized consideration of relevant aspects of the character and record of each convicted defendant before the imposition upon him of a sentence of death."49 Thus, following these decisions, a death penalty sentence is constitutional under the Eighth Amendment if the judge is permitted to first consider mitigating factors. ${ }^{50}$

One broad mitigating factor that would become crucial in Miller is the offender's youth. ${ }^{51}$ The importance of this factor has rapidly grown over the past few decades. In Eddings v. Oklahoma, ${ }^{52}$ the Court recognized that youth is a "time and condition of life when a person may be most susceptible to influence and to psychological damage."53 Furthermore, the Court discussed how minors are typically less mature and responsible than adults, ${ }^{54}$ and stated that a minor's age, background, and mental and emotional development must be considered in imposing a death sentence. ${ }^{55}$

The Court added to this reasoning in Tison $v$. Arizona ${ }^{56}$ by tying the penological justification for retribution to the imposition of death on youth offenders. ${ }^{57}$ The Court stated that the "heart of the retribution rationale is that a criminal sentence must be directly related to the personal culpability of the criminal offender." ${ }^{58}$ In other words, the sentence must be proportional to the offender's culpability, which is measured against the offender's maturity level, emotional development, and background. ${ }^{59}$

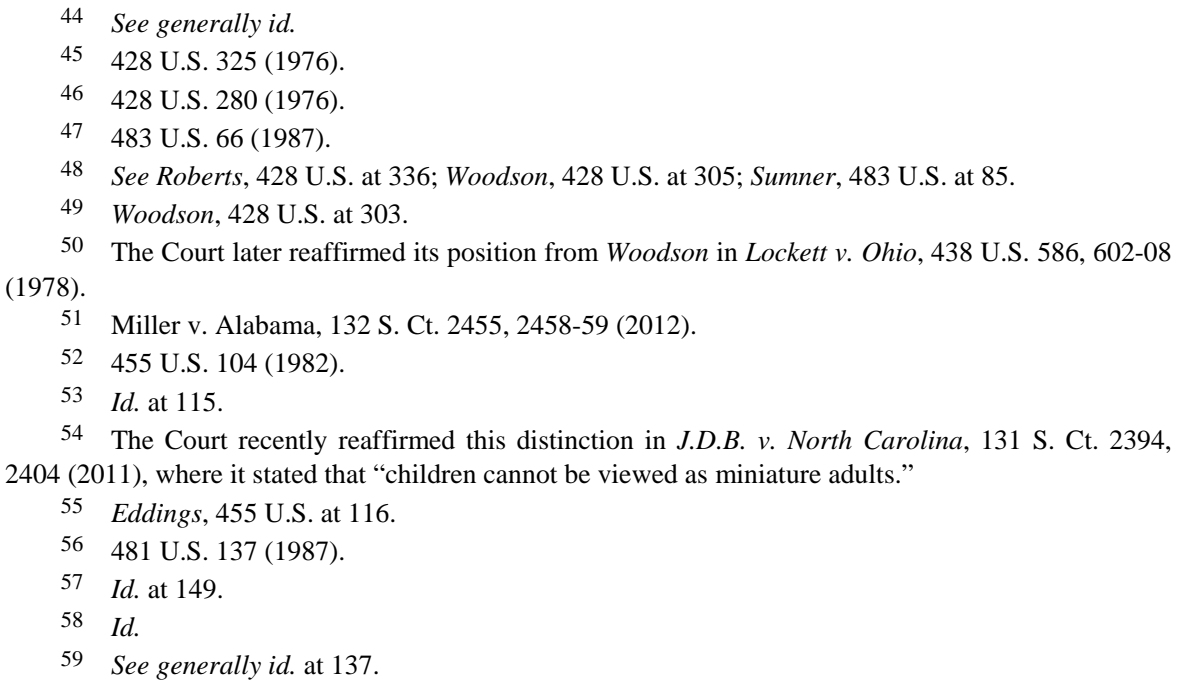


Later in Johnson v. Texas, ${ }^{60}$ the Court succinctly summed up its reasoning for the importance of considering an offender's youth before imposing a death sentence. ${ }^{61}$ The Court stated that the "relevance of youth as a mitigating factor derives from the fact that the signature qualities of youth are transient; as individuals mature, the impetuousness and recklessness that may dominate in younger years can subside.”62

\section{Categorical Bans on Sentencing Practices}

By the early 1980s, the Court had firmly established its reliance on the principles of proportional punishment, the objective determination of society's standard of decency, and the consideration of mitigating factors, especially youth. Moving forward, the Court would rely on these principles and rationales to begin implementing categorical bans on the imposition of the death penalty for particular groups.

For example, in Enmund $v$. Florida, ${ }^{63}$ the Court held that the "imposition of the death penalty on one... who aids and abets a felon in the course of which a murder is committed by others but who does not himself kill, attempt to kill, or intend that a killing take place” is unconstitutional under the Eighth Amendment. ${ }^{64}$ In Atkins v. Virginia, ${ }^{65}$ the Court prohibited the imposition of the death penalty on mentally handicapped criminals. ${ }^{66}$ And in Kennedy v. Louisiana, ${ }^{67}$ the Court found that rape offenders could not be sentenced to death where the victim died after the incident, if "the crime did not result, and was not intended to result, in the death of the victim." 68

These decisions are important because they constructed the framework for courts to follow in analyzing the constitutionality of a sentence. However, the two most groundbreaking decisions for juvenile sentencing under the Eighth Amendment, which the Court most heavily relied on in Miller, are Roper v. Simmons ${ }^{69}$ and Graham v. Florida. ${ }^{70}$

Both decisions created categorical bans on sentencing practices

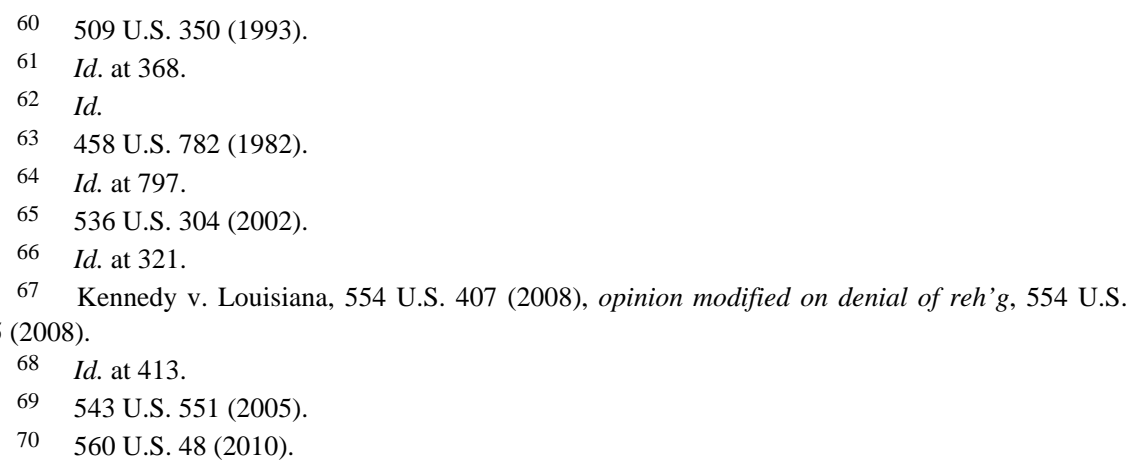


directly pertaining to juveniles. ${ }^{71}$ While the ban in Roper prohibited the imposition of the death penalty on offenders who were minors when they committed their capital offenses, ${ }^{72}$ the ban in Graham reached new territory, as it prohibited a court from imposing a life-without-thepossibility-of-parole sentence on a juvenile for a non-homicide offense. ${ }^{73}$

In Roper, the offender committed first-degree murder when he was seventeen-years-old and was later convicted and sentenced to death. ${ }^{74}$ The Court synthesized the abundance of case law that has been described above into a two-part analysis: 1) "a review of objective indicia of consensus, as expressed in particular by the enactments of legislatures;" and 2) a determination "in the exercise of [the Court's] own independent judgment, whether the death penalty is a disproportionate punishment for juveniles." ${ }^{75}$

For the first factor, the Court determined that a majority of states had already enacted laws prohibiting the death penalty for juveniles, and in the states lacking this prohibition, actual sentences of death for juveniles was exceedingly rare. ${ }^{76}$ Thus, "the rejection of the juvenile death penalty in the majority of States; the infrequency of its use even where it remains on the books; and the consistency in the trend toward abolition of the practice," showed that there was no national consensus in favor of this punishment for juveniles. ${ }^{77}$

As to the second factor, the Court stated that capital punishment should be reserved for the worst offenders and described three differences that set juveniles apart from this status of offender: ${ }^{78} 1$ ) juveniles are less mature and responsible; 2) "juveniles are more vulnerable or susceptible to negative influences and outside pressures, including peer pressure;" and 3) juveniles have personality traits that are "less fixed."79 These differences can result in the lessened or diminished culpability of a juvenile. ${ }^{80}$

Furthermore, the Court reasoned that the juvenile's diminished culpability makes a retributive punishment excessive, and there is no evidence that the death penalty served as an effective deterrent. ${ }^{81}$ While the Court acknowledged that there is always the rare possibility that a

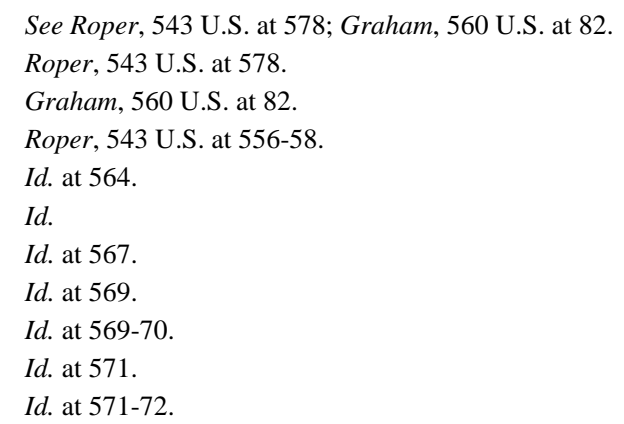


competent, mature, and depraved juvenile, who committed a despicable crime, is deserving of the death penalty, it would be too difficult for courts to make accurate determinations, and too dangerous to risk them being wrong. ${ }^{82}$

In Graham, the juvenile was sentenced to life-without-the-possibilityof-parole ${ }^{83}$ for non-homicide offenses. ${ }^{84}$ Again, the Court used the same two-part analysis described earlier. ${ }^{85}$ The Court looked at actual sentencing practices across the States, and concluded that the imposition of lifewithout-the-possibility-of-parole sentences on juveniles was rare. ${ }^{86}$

Furthermore, the fact that some states have dual-statute systems, where the juvenile is eligible for transfer to adult court under one statute, and then sentenced according to the sentencing guidelines for adults found in another statute, does not sufficiently indicate that a state legislature intended for juveniles to receive such a harsh penalty. ${ }^{87}$

The Court in Graham then reaffirmed the Roper rationale, describing how the differences between juveniles and adults create lessened culpability for juveniles. ${ }^{88}$ Furthermore, the Court likened life-without-the-possibilityof-parole for juveniles to a death sentence by highlighting the shared characteristics of the two. ${ }^{89}$ The Court stated that both create a "forfeiture that is irrevocable," and both "deprive[] the convict of the most basic liberties without giving hope of restoration."

The Court also considered the penological justifications, or lack thereof, for retribution, deterrence, incapacitation, and rehabilitation as they pertain to this harsh penalty for juveniles. ${ }^{91}$ The Court stated that a "sentence lacking any legitimate penological justification is by its nature disproportionate to the offense," ${ }^{\text {, }}$ and concluded that none of these punishment goals justify life-without-the-possibility-of-parole sentences for juveniles who commit non-homicidal crimes. ${ }^{93}$

The Court found that a juvenile's lessened culpability makes

$82 \quad$ Id. at 573.

83 The juvenile was sentenced to life in prison, but because Florida had previously abolished its parole system, the juvenile had no possibility to be released, other than by executive clemency.

84 Graham v. Florida, 560 U.S. 48, 56-57 (2010).

85 Id. at 61-73.

86 Id. at 62-67.

87 Id. at 66-67.

88 Id. at 67-70.

89 Id.

$90 \quad$ Id. at 69-70.

91 Id. at 71.

92 Id.

93 Id. 
retribution and deterrence ineffective here. ${ }^{94}$ Retribution is directly tied to the criminal's culpability, and deterrence requires criminals to consider the consequences of their crimes prior to committing them, which juveniles are not likely to do anyway. ${ }^{95}$

Incapacitation would be ineffective due to the extreme difficulty courts would face in trying to predict a juvenile's future threat to society, as he matures and reaches adulthood. ${ }^{96}$

As for the goal of rehabilitation, a life-without-the-possibility-ofparole sentence completely precludes its purpose for obvious reasons. ${ }^{97}$ While the Court made it clear that a state did not have to guarantee a juvenile's release at some point, states are required to provide "all juvenile nonhomicide offenders a chance to demonstrate maturity and reform."98

\section{EXAMINING MILLER}

With the precedent of Roper and Graham in place, which heavily relied on the youth argument, ${ }^{99}$ the Court was ready to extend these arguments to another previously untouched area of sentencing for juveniles, mandatory life-without-the-possibility-of-parole for homicide offenders. While the type of sentence being addressed is different, the Court's simple, but important, theme remains the same: "that imposition of a State's most severe penalties on juvenile offenders cannot proceed as though they were not children." 100

In Miller, the Court decided two companion cases, both of which dealt with juveniles who were convicted of murder and sentenced to mandatory life-without-the-possibility-of-parole. ${ }^{101}$ The key fact in both cases was that neither court was permitted to use discretion in deciding the proper sentences. ${ }^{102}$

\section{A. Facts of the Two Cases}

One of the cases involved petitioner, Kuntrell Jackson (“Jackson”), a

94 Id.

95 Id.

$96 \quad$ Id. at 72.

97 Id. at 73-75.

98 Id. at 79.

99 As discussed earlier, the Court has repeatedly argued that minors may have lessened culpability due to their maturity level, mental and emotional development, and transitory characteristics, which also negate the penological justifications for the sentences. See Graham, 560 U.S. at 70-74.

100 Miller v. Alabama, 132 S. Ct. 2455, 2466 (2012).

101 Id. at 2460

102 Id. 
fourteen-year-old who robbed a store with two other juveniles. ${ }^{103}$ While Jackson waited outside, the other two juveniles entered the store to commence the robbery. ${ }^{104}$ Shortly after Jackson entered the store, one of the other juveniles shot and killed the store clerk. ${ }^{105}$ Arkansas law allowed the prosecutor to use discretion in determining whether to charge Jackson as an adult for this serious crime. ${ }^{106}$

The prosecutor charged Jackson as an adult with capitol felony murder and aggravated robbery, and the trial court refused to transfer the case to juvenile court after considering the facts, a psychological examination, and Jackson's arrest history. ${ }^{107}$ Pursuant to Arkansas law, ${ }^{108}$ the only permissible sentence for these crimes was life-without-the-possibility-ofparole. ${ }^{109}$ Jackson later filed a state petition for habeas corpus, but the circuit court dismissed it, and the Arkansas Supreme Court affirmed the dismissal. ${ }^{110}$

Petitioner Evan Miller ("Miller") was also fourteen years old when he committed his crime. ${ }^{111}$ Miller attempted to steal money from the unconscious victim while drinking and doing drugs at the victim's trailer. ${ }^{112}$ However, the victim awoke during this act, and grabbed Miller's throat. ${ }^{113}$ After Miller's friend hit the victim with a baseball bat, allowing Miller to go free, Miller repeatedly hit the victim with the bat. ${ }^{114}$

Miller and his friend then lit the trailer on fire, killing the victim. ${ }^{115}$ Alabama law ${ }^{116}$ also allowed the prosecutor to transfer the case to adult court. ${ }^{117}$ Miller was subsequently convicted of murder in the course of arson, ${ }^{118}$ which carried a minimum punishment of mandatory life-withoutthe-possibility-of-parole. ${ }^{119}$ The Alabama Court of Criminal Appeals affirmed, and the Alabama Supreme Court denied review. ${ }^{120}$

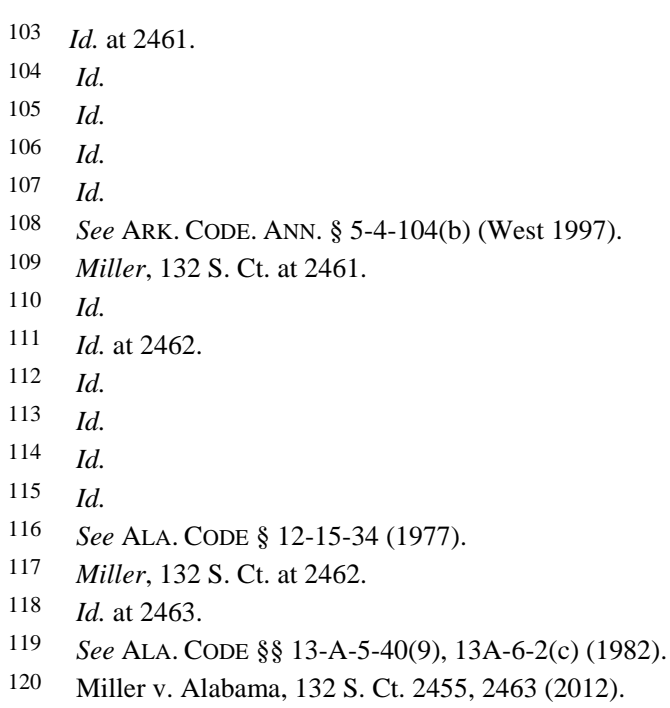


[Vol. 9:159

The United States Supreme Court then granted certiorari in both cases and held that sentencing juvenile homicide offenders to mandatory lifewithout-the-possibility-of-parole is unconstitutional under the Eighth Amendment. ${ }^{121}$

\section{B. Court's Reasoning}

The Court first pointed out that the purpose of the Eighth Amendment is to ensure that proportionate sentencing practices are used. ${ }^{122}$ Moreover, the Court considered the "evolving standards of decency" in society when determining what marks a proportionate sentence. ${ }^{123}$ The two lines of precedent addressing proportionate sentencing are those: 1) creating categorical bans on sentences "based on mismatches between the culpability of a class of offenders and the severity of the penalty;" and 2) requiring individualized sentencing schemes for the death penalty. ${ }^{124}$

The Court noted that many of the cases creating categorical bans, such as Roper $^{125}$ and Graham, ${ }^{126}$ were aimed at juveniles because of their lessened culpability. ${ }^{127}$ These cases established that "children are constitutionally different from adults for purposes of sentencing." 128 The Court justified this gap between adults and juveniles ${ }^{129}$ by citing the three differences between the two groups mentioned in Roper. ${ }^{130}$ Furthermore, the Court cited the reasoning set out in Graham ${ }^{131}$ for why the "distinctive attributes of youth diminish the penological justifications for imposing the harshest sentences on juvenile offenders."132

Moreover, the Court pointed out that the discussion in Graham about the mental and environmental characteristics affecting juveniles is not crime specific, and thus, applies to any life-without-the-possibility-of-parole sentence imposed on a juvenile. ${ }^{133}$ Mandatory sentencing practices prevent a sentencing court from considering a juvenile's youth and attendant circumstances. ${ }^{134}$ Without this consideration, a court would be unable to

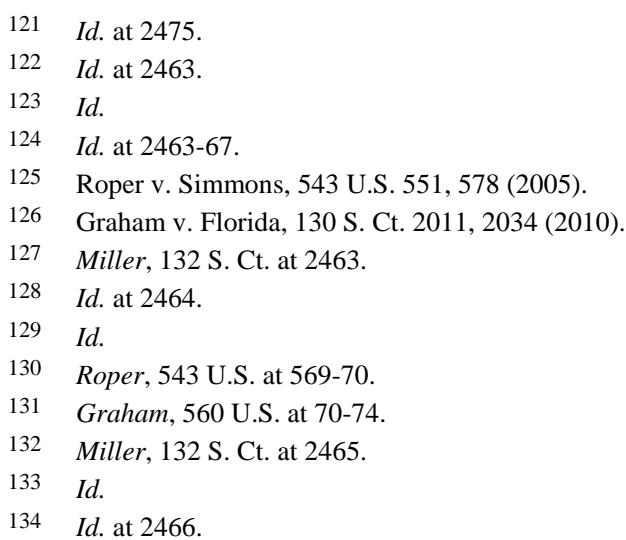


ensure that a juvenile received a punishment that is proportional to the offense. $^{135}$

The Court then reiterated its view on the similarities between a death sentence and a life-without-the-possibility-of-parole sentence for juveniles. ${ }^{136}$ These similarities make it that much more crucial $^{137}$ that a court is able to consider any and all mitigating factors when imposing such a harsh sentence on a juvenile. ${ }^{138}$ Prior to applying its rationale to the facts, the Court nicely summed up its position:

Mandatory life without parole for a juvenile precludes consideration of his chronological age and its hallmark features-among them, immaturity, impetuosity, and failure to appreciate risks and consequences. It prevents taking into account the family and home environment that surrounds him-and from which he cannot usually extricate himself-no matter how brutal or dysfunctional. It neglects the circumstances of the homicide offense, including the extent of his participation in the conduct and the way familial and peer pressures may have affected him .... And finally, this mandatory punishment disregards the possibility of rehabilitation even when the circumstances most suggest it. ${ }^{139}$

Jackson neither killed, nor intended to kill, the victim on the night of the robbery. ${ }^{140} \mathrm{He}$ was sentenced to life-without-the-possibility-of-parole for merely aiding and abetting. ${ }^{141}$ His age, ability to assess the risk of his actions, and family background go to the culpability analysis. ${ }^{142}$ For example, Jackson's mother and grandmother had shot individuals in the past. $^{143}$

As for Miller, not only was he on drugs and inebriated at the time of his crime, he also had a disturbing "pathological background."144 He was physically abused by his stepfather, neglected by his alcoholic and drugaddicted mother, in and out of foster care, and suicidal. ${ }^{145}$ Thus, the Court stated that although these circumstances certainly do not excuse Miller's

137 The Court discussed the dangers of mandatory sentencing, such as sentencing fourteen and seventeen-year-olds alike, as well as the shooter and the accomplice. Id. at 2467-68.

138 Miller, 132 S. Ct. at 2467.

139 Id. at 2468.

$140 I d$.

141 Id. at 2468.

142 Id.

143 Id.

144 Id. at 2469.

145 Id.
} 
behavior in any way, they are relevant to consider before imposing a sentence of life-without-the-possibility-of-parole. ${ }^{146}$

\section{Opposing Arguments}

The Court addressed and rejected the respondents' two opposing arguments that: 1) the holding here conflicts with Eighth Amendment precedent; and 2) "individualized circumstances [already] come into play in deciding whether to try a juvenile offender as an adult."

First, the respondents contended that the Court's previous case, Harmelin v. Michigan, ${ }^{148}$ precluded the holding here because the Court there upheld a mandatory life-without-the-possibility-of-parole sentence for a drug charge, "reasoning that a sentence which is not otherwise cruel and unusual does not becom[e] so simply because it is mandatory."149 Moreover, the Court in Harmelin "refused to extend [the individualized sentencing for death penalty cases] command to noncapital cases 'because of the qualitative difference between death and all other penalties." "150

In dismissing this argument, the Court in Miller explained that Harmelin was not intended to apply to sentencing for juveniles. ${ }^{151}$ The Court reasoned that sentencing rules frequently differ for adults and juveniles, and that these sentencing exceptions are by no means an "oddity in the law." 152 The Court aptly remarked that "if [] 'death is different,' children are different [too]." ${ }^{\text {"153 }}$ Thus, the Court found that Miller does not conflict with Harmelin. ${ }^{154}$

Second, the respondents contended that "because many States impose mandatory life-without- parole sentences on juveniles, ${ }^{155}$ [the Court cannot] hold the practice unconstitutional."156 The Court responded that the supposed evidence of national consensus actually does not distinguish this situation from other cases where the Court found that a sentencing practice omitted).

150 Id. (quoting Harmelin).

151 Id.

152 Id.

153 Id. (quoting Harmelin).

154 Id. at 2470.

155 Id. at 2471 (respondents pointed to statistics indicating that twenty-nine jurisdictions impose a mandatory life- without-the-possibility-of-parole sentence for some juveniles convicted of murder in adult court).

156 Id. at 2470. 
violated the Eighth Amendment. ${ }^{157}$

Furthermore, of the twenty-nine jurisdictions imposing a mandatory life-without-the-possibility-of-parole sentence for juveniles convicted of murder, "more than half" do so through the combination of two independent statutes. ${ }^{158}$ "One allowed the transfer of certain juvenile offenders to adult court, while another ... set out the penalties for any ... individuals tried there." ${ }^{\prime 159}$ The Court was not convinced that States actually intended for these two statutes to work in this way. ${ }^{160}$

The Court also dismissed the notion that the ability of courts in some jurisdictions to use discretion in transferring juveniles to adult court makes the Court's holding here unnecessary. ${ }^{161}$ First, the Court reasoned that the "decisionmaker typically will have only partial information... this early ... about either the child or the circumstances of his offense."162 And second, a sentencing judge in adult court has more sentencing options available to him than does the decisionmaker at a transfer hearing. ${ }^{163}$

For example, in adult court, the sentencing body can impose a "lifetime prison term with the possibility of parole or a lengthy term of years." "164 Thus, the Court concluded that a judge's discretion at the transfer stage does not substitute for the discretion utilized during post-trial sentencing in adult court. ${ }^{165}$

Based on these arguments and policy considerations, the Court held that sentencing juvenile homicide offenders to mandatory life-without-thepossibility-of-parole is unconstitutional under the Eighth Amendment. ${ }^{166}$ With the Miller decision in place, the burden now shifts to the lower courts across the nation to appropriately apply this holding to incarcerated juveniles who have been improperly sentenced, as well as to future cases.

In his dissent, ${ }^{167}$ Justice Thomas addressed how he thinks this decision will ultimately affect the lower courts. ${ }^{168}$ He argued that the Court's stating that discretionary life-without-the-possibility-of-parole sentences would be

157 Id. at 2471.

158 Id. at $2472-73$.

159 Id. at 2472.

160 Id. at 2472-73. While this argument is not highly persuasive, the national consensus consideration was not a significant factor utilized by the Court in reaching its decision.

161 Id. at 2474.

162 Id.

163 Id.

164 Id. at 2474-75.

165 Id. at 2475.

166 Id.

167 The author will not discuss here a concurring opinion and two additional dissenting opinions from Miller.

168 Miller, 132 S. Ct. at 2482. 
[Vol. 9:159

"uncommon ... may well cause trial judges to shy away from imposing life without parole sentences and embolden appellate judges to set them aside when they are imposed."169 This statement by the Court, Justice Thomas believes, is the Court's attempt to "shape the societal consensus of tomorrow." some courts and state entities are doing their best to avoid Miller's intent. ${ }^{171}$

\section{WAYS IN WHICH COURTS ARE ABIDING BY MILLER}

An evaluation of the various ways in which courts have responded in the wake of Miller shows that many courts are doing exactly what they should be doing: following the Court's intent in Miller that juvenile homicide offenders receive individualized sentencing. ${ }^{172}$ Certain positive trends have emerged in the actions taken thus far by courts. ${ }^{173}$ These actions can only be judged by their compliance, or lack thereof, with the Court's mandate as set forth in Miller last summer. The following sections identify the proper course of actions that have been taken in the wake of Miller.

\section{A. Remanding Mandatory Life-Without-The-Possibility-Of-Parole Cases for Resentencing Hearings}

The clearest form of compliance with Miller comes in the form of appellate courts that remanded cases in which mandatory life-without-thepossibility-of-parole sentences were imposed on defendants who were juveniles at the time they committed homicide offenses. The Court in Miller concluded its extensive opinion with a straightforward holding:

By requiring that all children convicted of homicide receive lifetime incarceration without possibility of parole, regardless of their age and age-related characteristics and the nature of their crimes, the mandatory sentencing schemes before us violate this principle of proportionality, and so the Eighth Amendment's ban on cruel and unusual punishment. ${ }^{174}$

Many courts across the country have construed these words to mean exactly what they say. From appellate courts in Texas, to Florida, to Pennsylvania, and California, decisions for remand and resentencing are pouring in, as courts far and wide do their part to ensure that juveniles affected by the

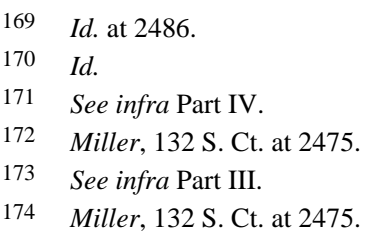


Miller holding receive their now constitutionally-protected right to individualized sentencing. ${ }^{175}$

Even in a Florida appellate case where the conviction and sentence were reversed for other reasons, the appellate court still took the time to mention the holding in Miller and warned that the "trial court should be mindful of Miller. ${ }^{\prime 176}$

\section{B. U.S. v. Maldonado: Considering Mitigating Factors from Miller ${ }^{177}$ \\ During Sentencing Stage of Initial Trial}

While nearly all of the cases to address Miller so far are from the appellate level, U.S. v. Maldonado ${ }^{178}$ is a post-Miller trial court level case that involved the conviction of a juvenile for homicide offenses and the imposition of a life sentence. ${ }^{179}$ In its opinion, the Maldonado court took the factors set forth in Miller into consideration prior to making a ruling. ${ }^{180}$

The court in Maldonado weighed the defendant's age, level of remorse, prior criminal history, "capacity or will to rehabilitate himself," a psychological evaluation, and "all of the 'hallmark features' associated with a person of that young age," against the nature and gravity of the crimes he was convicted of. ${ }^{181}$ Based on its analysis, the court in Maldonado still found a life sentence to be appropriate under the circumstances, ${ }^{182}$ which is fully in line with the Court's intent in Miller. ${ }^{183}$

\section{Properly Handling a Statutory Presumption of Life-Without-the- Possibility-of-Parole in California}

The appellate cases arising in California under Miller appear to be focused on California Penal Code Section 190.5(b), ${ }^{184}$ which, although not

175 See People v. Silva, No. B225127, 2012 WL 6721537 (Cal. Ct. App. Dec. 28, 2012); People v. Moffett, 148 Cal. Rptr. 3d 1465 (Cal. Ct. App. 2013); People v. Banks, No. 08CA105, 2012 WL 4459101 (Colo. App. Sept. 27, 2012); Rocker v. State, No. 2D10-5060, 2012 WL 5499975 (Fla. Dist. Ct. App. Nov. 14, 2012) (opinion withdrawn); Washington v. State, 103 So. 3d 917 (Fla. Dist. Ct. App. 2012); State v. Simmons, 99 So. 3d 28 (La. 2012); State v. Graham, 99 So. 3d 28 (La. 2012); State v. Brooks, No. 47,394-KA, 2012 WL 6163089, (La. Ct. App. Dec. 12, 2012); Commonwealth v. Knox, 50 A.3d 732 (Pa. Super. Ct. 2012); Commonwealth v. Lofton, 57 A.3d 1270 (Pa. Super. Ct. 2012); Wilson v. State, No. 14-09-01040, 2012 WL 6484718 (Tex. App. Dec. 13, 2012); Henry v. State, No. 05-1100676 CR, 2012 WL 3631251 (Tex. App. Aug. 24, 2012).

176 Miller v. State, 127 So. 3d 580, 587 (Fla. Dist. Ct. App. 2012).

177 Miller, 132 S. Ct. at 2468.

178 U.S. v. Maldonado, No. 09 Cr. 339-02, 2012 WL 5878673 (S.D.N.Y. Jan. 21, 2013).

179 Id. at $* 1$.

180 Id. at $* 9-10$

181 Id.

182 Id. at *10 (quoting Miller).

183 Miller v. Alabama, 132 S. Ct. 2455, 2468 (2012).

184 CAL. PENAL CODE $§ 190.5$ (b) (1990). 
mandatory, seemingly creates a presumption in favor of life-without-thepossibility-of-parole sentences for juveniles who commit a particular murder crime. ${ }^{185}$ Section 190.5(b) states that "[t]he penalty for a defendant found guilty of murder ... who was ... under the age of 18 years at the time of the commission of the crime, shall be confinement in the state prison for life without the possibility of parole or, at the discretion of the court, 25 years to life.”186

In three California appellate cases $^{187}$ arising under Miller, which all deal with this Section, the courts were able to resist the temptation to take the easy way out by simply proclaiming that the sentencing scheme is discretionary, and thus, not falling under Miller. The courts understood that Section 190.5(b) created the potential for a trial court to fail to provide a juvenile with individualized sentencing by merely imposing the proscribed life-without-the-possibility-of-parole sentence. ${ }^{188}$

In each case, the court assessed whether the trial court actually considered all potentially mitigating factors before imposing life sentences. ${ }^{189}$ Ultimately, all three sentences were approved because the sentencing courts took the mitigating factor of youth into consideration prior to imposing a sentence. ${ }^{190}$

\section{Remanding Discretionary Punishment Case For Resentencing Due to \\ Failure to Consider Mitigating Factors}

Another example of how courts are abiding by the spirit of Miller is Daugherty $v$. State, ${ }^{191}$ where the seventeen-year-old defendant was sentenced to life-without-the-possibility-of-parole for committing a seconddegree murder, as well as two counts of attempted second-degree murder, under a discretionary sentencing scheme in Florida. ${ }^{192}$ Again, the court could have justified affirming the sentence by pointing to the fact that this sentence was not mandatory, and thus not encompassed by Miller. However, the court in Daugherty chose to abide by the spirit of Miller and 
evaluated whether the trial court properly considered all mitigating factors before imposing this sentence. ${ }^{193}$

The court in Daugherty stated that, although this is a discretionary sentence, Miller requires that "judges must take an individualized approach to sentencing juveniles in homicide cases and consider factors which predict whether a juvenile is amenable to reform or beyond salvation." Moreover, the court here recognized that the Court in Miller "stressed the sentencing judge's responsibility" to consider the defendant's youth and how it makes him different, culpability-wise, from an adult. ${ }^{195}$

After evaluating the trial court's analysis prior to sentencing, the court in Daugherty concluded that while the trial court considered the defendant's remorse for committing the crimes, as well as his "upbringing," the trial court failed to "expressly consider" whether any mitigating factors related to youth are present and would "diminish" the justifications for the lifewithout-the-possibility-of-parole sentence. ${ }^{196}$ The court remanded the case for additional sentencing proceedings and made it clear that a life-withoutthe-possibility-of-parole sentence may still be imposed, so long as a thorough evaluation of the defendant's circumstances justified it. ${ }^{197}$

E. Striking Down Term-of-Years Sentences that "Amounts to the

Functional Equivalent of a Life Without Parole Sentence”198

In Miller, the Court stated that "we require ... [a sentencer] to take into account how children are different, and how those differences counsel against irrevocably sentencing them to a lifetime in prison.”199 While a sentencing scheme that imposes a mandatory life-without-the-possibilityof-parole sentence is the most obvious form of life imprisonment, a termof-years sentence ranging from 70 years, to 80 years, and even over 100 years in prison, creates these same issues. This is especially true when no parole date is provided, or when the parole date will not come until the inmate is at least well into his nineties.

While not a homicide case, People v. Caballero ${ }^{200}$ has rightly set the tone for how lengthy term-of-years sentences for juvenile homicide offenders should be treated under Miller. In Caballero, the defendant, who was sixteen years old at the time of his crimes, was convicted of three

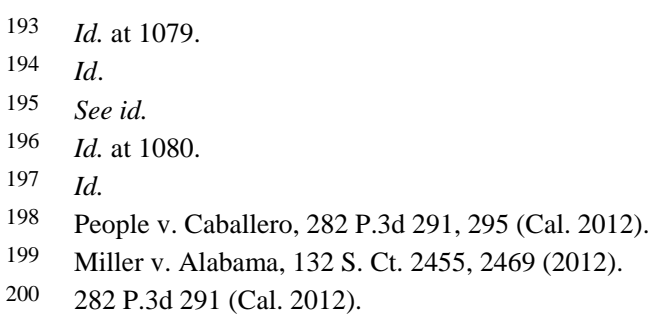


counts of attempted murder and sentenced to consecutive sentences totaling 110 years to life. ${ }^{201}$ While the analysis at the appellate level focused mostly on Graham, the court in Caballero did incorporate Miller into its discussion. ${ }^{202}$

The court in Caballero noted that the defendant would not become parole eligible for over 100 years and stated that this sentence "amounts to the functional equivalent of a life without parole sentence." ${ }^{203}$ Pursuant to the holding in Graham, the court here concluded that this sentence violated the Eighth Amendment because the "parole eligibility date ... falls outside the juvenile offender's natural life expectancy," and the defendant would have "no opportunity to 'demonstrate growth and maturity' to try to secure his release."204

Utilizing Caballero, the courts in two other California appellate cases that did involve juvenile homicide offenders who received lengthy term-ofyears sentences reasoned and concluded that both sentences violated Miller. ${ }^{205}$

In People v. Argeta, the fifteen-year-old defendant was convicted of murder and attempted murder and received an aggregate sentence of 100 years in prison. ${ }^{206}$ Moreover, the defendant would not become eligible for parole for at least seventy-five years, which, as the court here stated, "likely requires that he be in prison for the rest of his life." 207 Relying on Miller and Caballero, the court in Argeta remanded the case for resentencing, citing Caballero's reasoning that this type of sentence was the "functional equivalent of a life sentence without possibility of parole."208

In People v. Thomas, which involved another fifteen-year-old defendant, the trial court imposed an aggregate prison sentence of 196 years to life for a multitude of convictions, including first-degree murder. ${ }^{209}$ The court in Thomas quoted the trial judge's statement during sentencing which, not surprisingly, seemingly involved an attempt to side-step the Court's intent in Miller. ${ }^{210}$ The trial judge stated the following during sentencing: "I choose consecutive. And it's not going to be an LWOP [(i.e., a term of life without the possibility of parole)] because I'm prohibited to do that because 4th 987, 1016 (2012).

206 Argeta, 210 Cal. App. 4th at 1482.

207 Id.

208 Id

209 Thomas, 211 Cal. App. 4th at 1014-15.

210 See id. at 1015. 
of his age." ${ }^{211}$ He then went on to say that "there's no bright light at the end of the table for... [the defendant]... on this. [S]o I intend to [run] consecutive everything I can.,"212

The court in Thomas then stated that the trial judge was incorrect in believing that a 196 year sentence was not equivalent to a sentence of lifewithout-the-possibility-of-parole. ${ }^{213}$ Once again, the court in Thomas relied on Caballero's rationale, along with Miller, and remanded the case for resentencing. ${ }^{214}$

Whether the trial judge's attempt to side-step Miller's ban on mandatory life-without-the-possibility-of-parole sentences for juvenile homicide offenders was intentional, or just simply a misunderstanding, it shows how easily sentencing courts can manipulate the system with termof-years sentences. It will be up to appellate courts to continue to catch and correct these "mistakes" in the future.

\section{WAys That MiLLER CAN BE SIDE-STEPPED}

While many courts are following the spirit of Miller to the fullest extent, others, including entire states, appear to be evading the true purpose of this landmark decision in an effort to maintain the status quo. Whatever the reason for their actions, whether it be political, ideological, social, etc., it is important to recognize the mistakes early on because the constitutional rights of thousands of individuals may be detrimentally impacted.

\section{A. States Commuting Mandatory Life-Without-the-Possibility-of-Parole \\ Sentences to Lesser Sentences for Juvenile Homicide Offenders}

Maybe the most alarming and dangerous way that Miller can be sidestepped, due to how easy, public, and political it appears, is state entities, specifically governors and attorneys general, commuting juvenile homicide offenders' mandatory life-without-the-possibility-of-parole sentences to lesser sentences that still lack the element of individualization. Although the United States is still in the early stages of sentencing jurisprudence following Miller, two states are already making a big splash nationally with their envisioned solutions in the wake of the Court's decision. ${ }^{215}$

\footnotetext{
211 Id. (internal citations omitted).

212 Id.

213 Id. at 1016

214 Id.

215 See James Q. Lynch et. al, Branstad Commutes Life Sentences for 38 Iowa Juvenile Murderers, THE GAZETTE (July16, 2012), http://thegazette.com/2012/07/16/branstad-commutes-lifesentences-for-38-iowa-juvenile-murderers; Todd Cooper, Pardons Board Can't Speed Action on Juveniles' Life Terms, KEARNEY HUB (Dec. 14, 2012), http://www.kearneyhub.com/news/state/pardonsboard-can-t-speed-action-on-juveniles-life-terms/article_7b04feec-45f2-11e2-96c8-001a4bcf887a.html.
} 
[Vol. 9:159

1. Iowa

In Iowa, Governor Terry Branstad did not waste any time this past summer in stirring up a controversy over his solution following Miller to commute the crimes for the thirty-eight juvenile homicide offenders in Iowa, who all received mandatory life-without-the-possibility-of-parole sentences upon being convicted. ${ }^{216}$ Governor Branstad "ordered each of the offenders to instead serve a mandatory 60 years before being considered for parole."217 The Iowa governor explained his actions in a newspaper interview on July 16, 2012. ${ }^{218}$

According to the governor, he made this decision after he "carefully reviewed" the Court's ruling in Miller and "consulted with the Iowa Attorney General's Office, victims' families and county prosecutors."219 Governor Branstad further stated that he disagreed with the Court's decision in Miller, calling the decision "cruel and unusual punishment" for putting victims and their families through "agony.,"220 Moreover, the Governor elaborated on his concern for the emotional toll on the victims and their families in a separate news conference shortly after he made this controversial decision to commute the sentences. ${ }^{221}$

In that press conference, Governor Branstad stated that it was important to remember the victims and not force them to "relive the pain of the tragedies."222 Expressing his reasoning for his decision, he stated that the decision was made "to protect these victims, their loved ones' memories, and to protect the safety of all Iowans." 223 The Iowa Attorney General supported the Governor, stating that, "[Iowa] needs to do all it can within the confines of the U.S. Supreme Court decision to help protect public safety."224

However, whether commuting these juveniles' life-sentences to a 60 year sentence follows the spirit of Miller is doubtful. The Court in Miller explicitly stated in its holding that "our individualized sentencing decisions make clear that a judge or jury must have the opportunity to consider mitigating circumstances before imposing the harshest possible penalties for juveniles," i.e. life in prison. ${ }^{225}$ Imposing a blanket, universal sentence

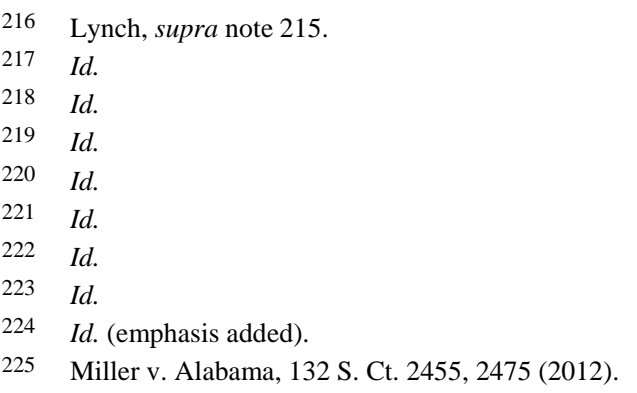


to all of these inmates defies any reasonable notion of what "individualized" means.

Moreover, while a 60 year sentence is not technically a mandatory lifewithout-the-possibility-of-parole sentence, it may become the "functional equivalent" of one, as stated in Caballero, depending on the circumstances. $^{226}$ If some of these juveniles were eighteen years old or older at the time of their convictions, they would still essentially be facing a lifetime in prison before ever becoming eligible for release. Thus, without any of them receiving the individualized sentencing intended by the Court in Miller, their constitutional rights are still being violated.

\section{Nebraska}

The Nebraska Board of Pardons ("Board") has also expressed its desire to commute the sentences of their juvenile homicide offenders who received mandatory life-without-the-possibility-of-parole. ${ }^{227}$ The Board consists of Nebraska Governor Dave Heieman, Attorney General Jon Bruning, and Secretary of State John Gale. ${ }^{228}$ Unlike in Iowa, the Nebraska Supreme Court delayed the plan after challenges were made from local defense attorneys. ${ }^{229}$ The Board's plan to commute the sentences of twenty-four Nebraska prisoners affected by Miller to sentences of 50, 70, 90, or even up to 100 years in prison arose in November, 2012. ${ }^{230}$ Furthermore, the Board's plan was based on similar rationale expressed by the Iowa Governor. ${ }^{231}$ The Attorney General's spokeswoman stated that the Nebraska Supreme Court's ruling to halt the Board's plan was “contrary to Attorney General Bruning's goal of protecting the public from violent criminals."232

As discussed earlier, automatically applying these sentences across the board fails to allow for each of the twenty-four prisoners to receive individualized sentencing hearings. ${ }^{233}$ Commuting sentences does not allow for a sentencer to consider the "mitigating qualities of youth" that the Court in Miller found essential to consider prior to imposing what amounts to life sentences for juveniles. ${ }^{234}$ Make no mistake, any sentence approaching 100 years, regardless of how young the defendant is, will ensure that the

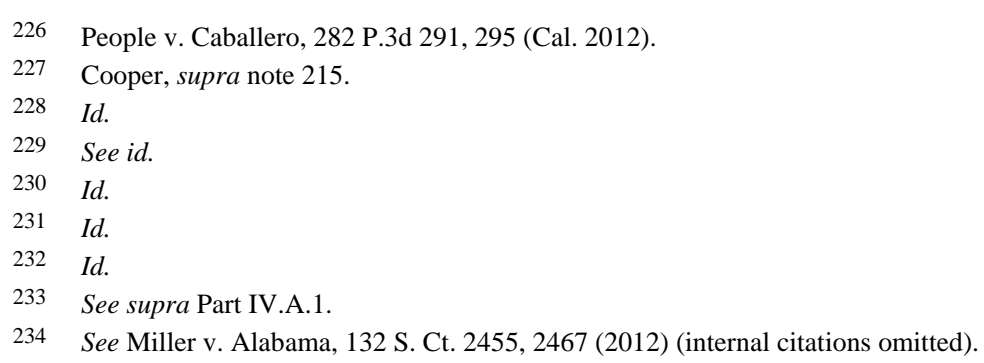


convicted exhale their final breaths in a prison cell.

B. Imposing Sentences at Trial that are the Functional Equivalent of Life in Prison Without Considering Mitigating Factors

As discussed earlier, imposing a lengthy term-of-years sentence can be the functional equivalent of life-without-the-possibility-of-parole because juveniles will spend the great majority of their lifetimes in a prison cell. While some courts, such as the one in Caballero, are effectively dealing with these types of sentences in light of the Court's ruling in Miller, there is always the strong possibility that courts may justify this sentence as not falling within the purview of Miller.

After all, the Court in Miller did state that, instead of sentencing a juvenile to mandatory life-without-the-possibility-of-parole, one alternative is "a lengthy term of years" sentence. ${ }^{235}$ However, the Court also emphasized that less-harsh, alternative sentences could be imposed through the use of "discretionary sentencing.",36 Discretionary sentencing, according to the Court, means "a judge or jury must have the opportunity to consider mitigating circumstances.”237

Furthermore, the Court in Miller reiterated what it stated in Graham about the similarities between life-without-the-possibility-of-parole sentences and the death penalty when it comes to juveniles. ${ }^{238}$ Referring to juveniles, the Court stated that "[i]mprisoning an offender until he dies alters the remainder of his life 'by a forfeiture that is irrevocable,"” and this is "especially harsh" because a juvenile "will almost inevitably serve "more years in prison and a greater percentage of his life in prison than an adult offender." "239 And just as the court in Caballero reasoned, a lengthy termsof-years sentence may prohibit a juvenile from seeking release until after his "natural life expectancy" has passed, and thus, is the "functional equivalent of life without parole." 240

Thus, a court simply imposing a lengthy term-of-years sentence on a juvenile for a homicide conviction without conducting individualized sentencing, which would see the juvenile locked up for a majority of his or her entire life, arguably contradicts the Court's intent in Miller.

One case that may act as a precursor for these kinds of sentences, as well as a guide post for courts who disagree with Miller's intent, is Bunch $v$.

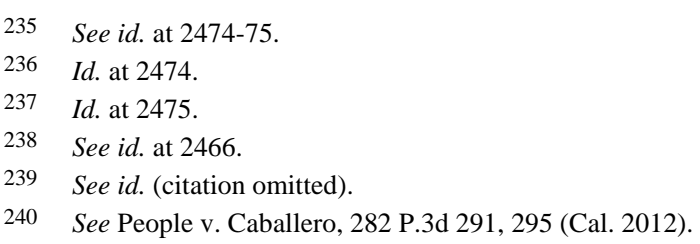


Smith, ${ }^{241}$ a Sixth Circuit case. In Bunch, a sixteen-year-old was convicted of multiple non-homicide offenses. ${ }^{242}$ The state trial court sentenced the juvenile to consecutive, fixed terms, totaling 89 years in prison. ${ }^{243}$ The trial court imposed the maximum term of imprisonment for several of the counts, while never appearing to consider any mitigating factors. ${ }^{244}$

The juvenile argued that his sentence was the "functional equivalent of life without parole" and "tantamount to a life sentence" under Graham. ${ }^{245}$ However the court in Bunch denied his appeal and distinguished his case from the type covered by Graham. ${ }^{246}$ The court stated that the main difference between the instant case and Graham is that the defendant in Graham was sentenced to life in prison while the juvenile here received consecutive, fixed term sentences. ${ }^{247}$

Moreover, the court in Bunch reasoned that Graham did not "address" juvenile offenders who receive lengthy sentences. ${ }^{248}$ The court even acknowledged that the 89-year sentence "may end up being the functional equivalent of life without parole," but because the juvenile did not receive a life sentence as in Graham, he is not entitled to an opportunity for meaningful release. ${ }^{249}$

Courts in the future may apply this same reasoning when it comes to juveniles raising appeals under Miller for 70, 80, or 90-year sentences. Courts may reason that Miller only covers mandatory life-without-thepossibility-of-parole sentences, and thus there is no constitutional barrier to prevent a court from imposing an 80-year sentence on a seventeen-year-old. While this interpretation may comply with Miller on its face, locking a juvenile up for the remainder of his life, without providing for the opportunity to consider mitigating factors, appears to be what the Court in Miller sought to avoid.

In Bunch, there was no question as to how the trial judge intended to sentence the juvenile offender, stating to the juvenile during sentencing that, "I just have to make sure that you don't get out of the penitentiary. I've got to do everything I can to keep you there." ${ }^{250}$ When judges believe that a juvenile defendant deserves to be in prison forever, some may turn to

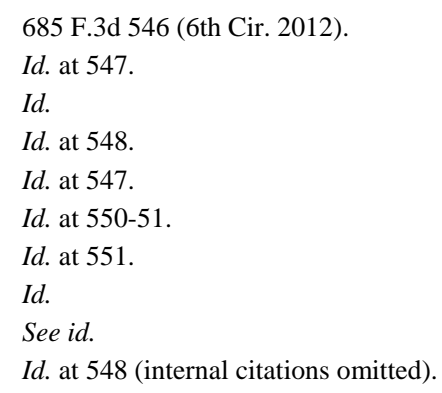


questionable methods such as these to ensure that a convicted juvenile cannot, and will not, cause any more harm to society. ${ }^{251}$ But the Court's intent in Miller was to prevent a juvenile from receiving "a sentence of life (and death) in prison" prior to first receiving an individualized sentencing hearing. ${ }^{252}$

\section{Hiding Behind Discretionary Sentencing Schemes Without Actually Considering Mitigating Factors}

Another route that courts may take that is similar in theory to imposing lengthy term-of-years sentences is refusing to remand cases for resentencing based on the fact that the imposed sentence was technically discretionary, and thus, does not fall within the scope of the Court's decision in Miller of banning mandatory life-without-the-possibility-ofparole sentences. Similar to a term-of-years sentence, a judge can choose to impose a life-without-the-possibility-of-parole sentence instead of being mandated to do so by the language of a state's criminal code.

This type of situation is obviously facially different from the defendants' situations in Miller, who were both convicted in states with mandatory life-without-the-possibility-of-parole statutes. ${ }^{253}$ And courts could simply use similar logic that the court in Bunch employed and justify their appeal denials by stating that the holding in Miller is limited to only mandatory life-without-the-possibility-of-parole sentences. ${ }^{254}$

An example of a court utilizing this type of justification in denying a juvenile's appeal for resentencing under Miller is State v. James. ${ }^{255}$ In James, the seventeen-year-old defendant was convicted of several homicide and non-homicide counts and sentenced to an aggregate prison term of 315 years in prison, with a requirement that nearly 268 of those years be served prior to becoming eligible for parole. ${ }^{256}$ The trial court imposed several consecutive and concurrent punishments subject to the No Early Release Act, ${ }^{257}$ without appearing to hold a hearing to consider any potential mitigating factors. ${ }^{258}$

The juvenile then appealed his sentence under Miller, arguing that

\footnotetext{
251 While Bunch provides an overt example of how a court can make an erroneous ruling under Miller, it shows how easily the spirit of Miller can be sidestepped.

252 Miller v. Alabama, 132 S. Ct. 2455, 2468 (2012).

253 Id. at 2461-63.

254 See Bunch v. Smith, 685 F.3d 546, 553 (6th Cir. 2012)

255 State v. James, No. 02-08-2875, 2012 WL 3870349 (N.J. Super. Court. App. Div. Sept. 7, 2012).

256 Id. at *1.

257 Id.

258 See id.
} 
"though not mandatory, [his sentence] equates to a life sentence without parole, and therefore, runs afoul of Miller." ${ }^{259}$ The state appellate court in James went on to deny this appeal by providing a very brief and undetailed explanation for its decision. ${ }^{260}$ The court pointed out that the defendants in Miller can be distinguished from the defendant here because those defendants were punished under mandatory sentencing schemes, absent any ability for a trial judge to use discretion. ${ }^{261}$

Furthermore, the court here mentioned that the Court's decision in Miller was based on two strands of precedent: 1) categorical bans on disproportionate punishments, and; 2) prohibiting the mandatory imposition of capital punishments. ${ }^{262}$ The court in James reasoned that the fact that the trial judge here had the discretion to impose different types of sentences rendered the Miller holding and its reliance on these two strands of precedent "inapposite."263

While the Court's holding in Miller, narrowly read, does only refer to mandatory life-without-the-possibility-of-parole sentences as being unconstitutional, ${ }^{264}$ courts like the one in James conveniently fail to mention what the Court had to say in the immediately succeeding paragraph to its holding (as well as ignoring the rest of the opinion). The Court in Miller stated that while its holding is sufficient to decide the two cases, they did not think it necessary to consider the defendants' argument for imposing a categorical ban on life-without-the-possibility-of-parole on juveniles. ${ }^{265}$ As Miller was a 5-4 opinion, it is easy to see why the majority would leave this question for another day in its effort to secure the five votes.

Moreover, the Court then stated the following: "[b]ut given all we have said in Roper, Graham, and this decision about children's diminished culpability and heightened capacity for change, we think appropriate occasions for sentencing juveniles to this harshest possible penalty will be uncommon."266 Thus, while the Court in Miller is not "foreclos[ing]" a sentencing court's ability to sentence a juvenile to life-without-thepossibility-of-parole, it clearly is not advocating for this type of sentence to automatically or even typically be used in the alternative. ${ }^{267}$

Additionally, this may be the Court's way of implicitly placing the

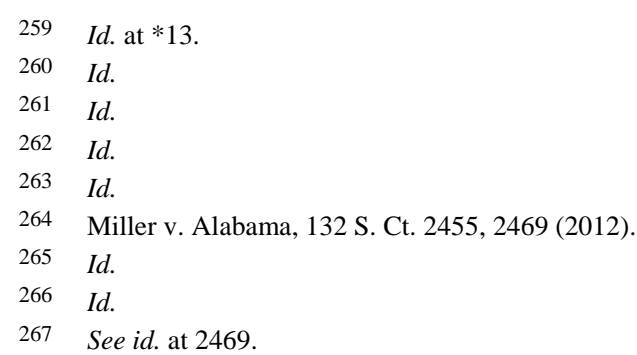


legal world on notice that a categorical ban on life-without-the-possibilityof-parole sentences for juveniles may be coming in the future. A close look at the trend of the Court's Eighth Amendment cases addressing sentencing schemes for juveniles seems to suggest that this type of ban may be likely in the future.

Chief Justice Roberts even acknowledged this point in his dissenting opinion. ${ }^{268}$ The Chief Justice stated that “[t]oday's holding may be limited to mandatory sentences, but the Court has already announced that discretionary life without parole for juveniles should be ... 'unusual.,”269 He further stated that the "Court's gratuitous prediction appears to be ... an invitation to overturn life without parole sentences imposed by juries and trial judges," and that the Court may be on its way to holding that the Eighth Amendment prohibits these sentences for juveniles. ${ }^{270}$

What does all of this mean? It means that the Court in Miller is troubled by the current landscape of juvenile sentencing, especially when it comes to juveniles serving their entire lives in a prison cell. Moreover, it appears that the words discretionary sentencing hold much more meaning and weight in the Court's minds than in the minds of a few lower courts.

\section{Looking for Alternative Sentencing Schemes}

One judicial methodology that may be employed by future courts applying Miller is to identify and use alternative sentencing options that are available. $^{271}$ Instead of providing for individualized sentencing as mandated in Miller, ${ }^{272}$ courts may look to their state statutes for the harshest, constitutionally permissible punishment available, ${ }^{273}$ or revive a previous version of the sentencing statute that would not technically violate the Court's holding in Miller. ${ }^{274}$

In People v. Banks, the defendant, fifteen years old at the time, was convicted of first-degree murder and sentenced to life-without-thepossibility-of-parole in Colorado. ${ }^{275}$ The appellate court correctly found that Miller bars this punishment and remanded the case for resentencing. ${ }^{276}$

268 See id. at 2481 (Roberts, C.J., dissenting).

269 Id.

270 See id.

271 See People v. Banks, No.09CA0105, 2012 WL 4459101, at *20-21 (Colo. App. Sept. 27, 2012); Partlow v. State, No.1D10-5896, 2013 WL 45743, at*3-8 (Fla. Dist. Ct. App. Jan. 4, 2013) (concurring).

272 Miller, 132 S.Ct. at 2475.

273 Banks, 2012 WL 4459101, at *20-21.

274 Partlow, 2013 WL 45743, at *4.

275 Banks, 2012 WL 4459101, at *1.

276 Id. at $* 20-21$. 
If the court in Banks had stopped at that point, there would be no issues to speak of; however, the court goes on to provide instructions to the lower court regarding what sentence should be imposed during resentencing. ${ }^{277}$

Instead of simply remanding for a resentencing hearing so that the lower court may consider mitigating factors, the court in Banks decided to apply Colorado's codified severability clause. ${ }^{278}$ This resulted in the court's instructing that the defendant be sentenced to life-imprisonment-with-thepossibility-of-parole after forty years. ${ }^{279}$ Although the Court in Miller was focused on eliminating mandatory life-without-the-possibility-of-parole sentences, ${ }^{280}$ the majority of the opinion is devoted to detailing the legal differences between adults and juveniles, and how these differences need to be considered before imposing a sentence with the potential for a lifetime spent in prison. ${ }^{281}$

Moreover, the Court in Miller even explicitly stated that "Roper and Graham emphasized that the distinctive attributes of youth diminish the penological justifications for imposing the harshest sentences on juvenile offenders."282 But in Banks, the court was doing its best "to impose the most serious penalty that is constitutionally permissible for such offenders."283

A fair reading of Miller would suggest that the point is not to merely impose the harshest penalty possible, but rather to make a justified sentencing determination based on all of the relevant information available to the court, including factors associated with the defendant's youth.

The concurrence in Partlow v. State brings to light a slightly different proposition than Banks, but is similarly based on an apparent effort to sidestep Miller. ${ }^{284}$ In Partlow, the court correctly reversed the juvenile defendant's mandatory life-without-the-possibility-of-parole sentence for resentencing. ${ }^{285}$ While Judge Makar agreed with the remand for resentencing under Miller, he wrote separately to propose that Florida courts should revive the state's previous sentencing scheme, which would have imposed sentences of life-with-the-possibility-of-parole after twentyfive years. $^{286}$

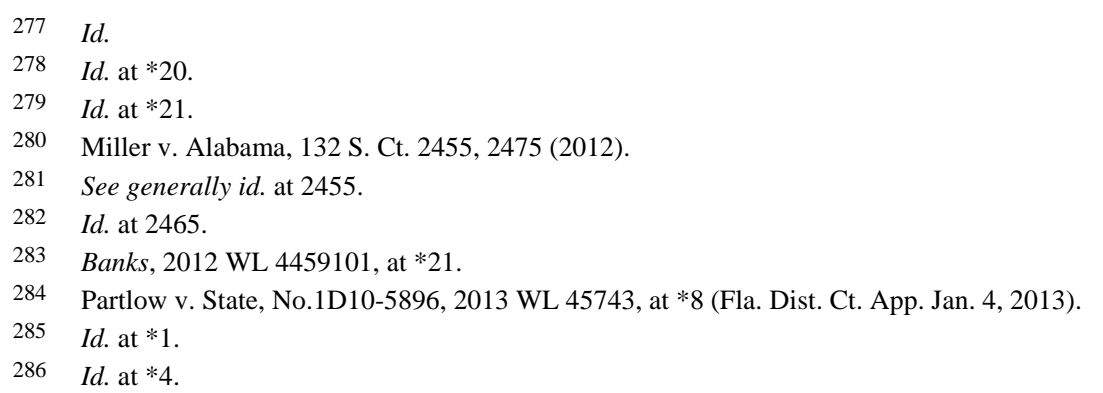


With the current sentencing scheme for juvenile homicide offenders in Florida being ruled unconstitutional by the Miller Court, Judge Makar believed that reverting back to the old sentencing scheme, which does not involve a mandatory life sentence, would comply with the holding in Miller. ${ }^{287}$ He stated that reverting to this previous sentencing scheme would not contrast with the "individual-centric approach to sentencing juveniles" in Miller because a sentence that allows for parole is "quantitatively and qualitatively a far different sentence from mandatory life without parole.”288

While not unreasonable, Judge Makar's argument is still somewhat contradictory. Judge Makar managed to openly acknowledge that the Court's intent in Miller was for an "individual-centric approach,"289 while at the same time arguing for an across-the-board imposition of this alternative sentence. ${ }^{290}$ The problem with across-the-board sentencing is that it fails to provide each juvenile previously sentenced to a mandatory life-without-thepossibility-of-parole sentence with the ability to receive an individualized resentencing hearing, which would allow the court to consider any and all mitigating factors.

Granted, if a court imposes a 75 year sentence with the possibility of parole after 25 years, then the argument that the juvenile would not have any meaningful opportunity for release is obviously weakened. But what if the possibility of parole is after 40 years of incarceration, as in Banks? ${ }^{291}$ Or 60 years? This becomes a much closer question worth analyzing before states decide to take any sweeping legislative steps.

Judge Makar later points out that it may be "too costly [for the State] to conduct potentially burdensome youth-mitigating hearings in these cases; mitigation litigation is expensive.”292 Additionally, some may argue that it would be difficult for any court to recreate or replicate the circumstances surrounding cases that may have originally occurred ten, twenty, or even thirty years ago. Not to mention the emotional turmoil that the victims' families and loved ones would have to endure once again, as the Governor from Iowa pointed out. ${ }^{293}$

While these are important concerns and should be addressed if possible, any proposed solution to these concerns cannot trample the constitutionally guaranteed right of another. The Court in Miller made no mention of these concerns, focusing instead on correcting what it believed

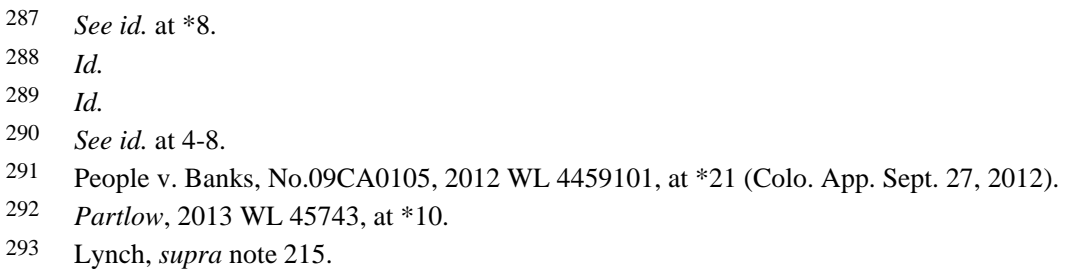


to be the most troublesome issue presented to it by the parties that day: a violation of thousands of juveniles' constitutional right against cruel and unusual punishment.

\section{CONCLUSION}

It is clear from the Court's recent record that the way juveniles are to be perceived and treated under the law is evolving and crystallizing with every new decision. The Eighth Amendment, as it applies to the youth of America, has taken on a distinct meaning and a unique set of principles for all courts across the nation to adopt and abide by, whether agreeable or not. Society recognizes the cognitive, emotional, and developmental differences between adults and juveniles, and these differences are reflected all around us.

From the disparities in legal rights and obligations owned and owed by adults and juveniles, to the endless volumes of academic studies and research indicating why and how juveniles are different, it would be difficult, to say the least, for anyone to enthusiastically argue against the widely accepted idea that individuals under the age of eighteen are generally less emotionally mature, cognitively developed, and "unsalvageable" when compared to adults.

This is not to say that juveniles cannot commit unspeakable and unthinkable crimes, deserving of the harshest penalties available under the criminal justice system. However, as the Court realized in Miller, the only true, fair, and constitutional way to determine if a juvenile's devastating crime is deserving of a de facto death sentence, such as life-without-thepossibility-of-parole, is for a sentencing court to take into consideration any and all mitigating factors of youth that may exist prior to imposing this sentence on a juvenile homicide offender.

Maybe this evaluation will turn up nothing worthy of lessening the juvenile's punishment, and maybe a life-without-the-possibility-of-parole sentence is exactly what a convicted juvenile has earned with his crimes. The Court is fine with that conclusion in the most deserving of occasions. But if this conclusion is formed, and this punishment imposed, in the absence of a full consideration of mitigating factors, then sentencing courts are not abiding by the Court's intent.

The juvenile justice system was founded on an ideal that somehow was forgotten and lost over time: juveniles can be rehabilitated. The Court seems to be making an effort to revive this ideal by limiting the sentencing abilities of lower courts when it comes to juveniles. Despite this effort, courts and state entities are having little difficulty finding ways to side-step the intent of Miller, and there may be no way to stop them without further action from the Court. 
[Vol. 9:159

The Court should explicitly address whether actions such as commuting sentences, imposing lengthy term-of-years sentences without a meaningful opportunity for release, and reverting to older sentencing schemes, all of which lack any individualized sentencing mechanism, are sufficient to satisfy the spirit of Miller. If these actions are not what the Court had in mind, as I believe is the case, then the Court should lay out exactly what type of procedure or individual hearing should be implemented, and in what circumstances, to ensure that juveniles' constitutional rights are not violated. 